\title{
APPROACH TO SOLVING THE E-WASTE PROBLEM - CASE STUDY GHANA
}

\author{
A. HOELTL ${ }^{1}$, R. BRANDTWEINER ${ }^{2} \&$ R. MÜLLER ${ }^{2}$ \\ ${ }^{1}$ Department for Management and Economics, Danube University Krems, Austria. \\ ${ }^{2}$ Institute of Information Management \& Control, Vienna University of Economics and Business, Austria.
}

\begin{abstract}
The market for electrical devices still continues to increase all over the world and as a consequence the quantity of waste in the category of electronics rises. A huge proportion of the electronic waste is exported from the industrial countries to developing countries, in order to save costs, and also because of too few recycling plants in industrial countries. The significant environmental and social problem in this context is that the electronic devices are mostly recycled in informal plants. Thereby the burden for the people as well as the environment increases because e-waste includes a lot of toxic substances. The negative impacts are already obvious in countries of importation. This paper will illustrate this on the basis of the case study in Ghana in Africa. The problem is evident, and research, business as well as governments aim to counter this development. The paper will investigate the current approaches employed for solving the e-waste problem with respect to legal options and also regarding voluntary agreements and the provision of information about the actual situation to the consumers.

Keywords: EEE, electronic waste, e-waste export, Ghana, recycling, WEEE, environmental and social problems.
\end{abstract}

\section{INTRODUCTION}

After the market launch of the mobile phone Apple iPhone 5S, in September 2013, 51 million devices had been sold within the first three months [1]. Just one year later the, next generation, iPhone 6 was rolled out. Such short new product launch cycles hint at the anticipated limited life span of these devices.

Additionally, due to its construction, a new mobile phone is generally cheaper than the cost of repairing an old one. As a result, the number of redundant mobile phones increases annually, adding to the volume of recycling needed.

Finally, storage presents additional problems. Electrical devices contain problematic subtances such as lead, cadmium and mercury ${ }^{6}$, which are dangerous for the environment in case of incorrect treatment [2].

According to Schwarzer et al. [3], the volume of waste resulting from electrical and electronic equipment (WEEE) worldwide was between 20 and 50 million tonnes in 2007.

Within the European Union the annual increase of e-waste is $2 \%$ to $5 \%$ higher than the increase in other waste categories. The current capacity for professional recycling in the producing countries is insufficient and as the substances involved are toxic or in other ways harmful to the environment the recycling process is very costly. Thus, companies sell large quantities of e-waste to developing countries, although the trade with WEEE is not allowed in many industrial countries. Often, the e-waste is declared as developing material aid. Recipient countries such as China, India or Ghana import e-waste thinking they would be able to bypass the 'digital divide' [4]. The recycling infrastructure as well as the required legal framework in these countries is rarely developed. As a consequence, e-waste often ends up in 'scrap yards', waste deposits where the devices are treated with very rudimentary tools, without consideration for people and the environment [5]. 
The paper aims, on the one hand, to show the problems in the context of electronic devices and e-waste, while on the other hand demonstrating different approaches for reducing or solving the e-waste problem.

\section{ADVERSE EFFECTS OF INFORMAL RECYCLING - CASE STUDY GHANA}

A key question is, 'At which point is an electronic device considered as electronic waste?' Also we need to consider, 'Why does this waste category grow faster than other categories?' Furthermore, 'Why is it profitable for exporting companies to transport and trade redundant devices over such long distances?'

\subsection{Definition of e-waste}

The definition of e-waste is crucial for the global handling of e-waste problems. First of all, a definition of electrical and electronic equipment (EEE) is required. Step [6] describes EEE in the following way: 'Any household or business item with circuitry or electrical components with power or battery supply.' This definition is broad based to encompass devices in private households as well as in companies. A device has to have electronic components that are current-carrying by a cable or an accumulator. The European Union's definition of EEE is given by the Directive (2012/19/EU): 'Electrical and electronic equipment or EEE means equipment which is dependent on electric currents or electromagnetic fields in order to work properly and equipment for the generation, transfer and measurement of such currents and fields and designed for use with a voltage rating not exceeding 1000 volts for alternating current and 1500 volts for direct current.' [7] According to the same Directive, the definition of WEEE is: 'Waste electrical and electronic equipment or WEEE means electrical or electronic equipment which is waste within the meaning of Article 3(1) of Directive 2008/98/EC, including all components, sub-assemblies and consumables which are part of the product at the time of discarding.' The European Union distinguishes between 10 categories of EEE and WEEE, shown in Table 1.

With respect to legal issues, it is important to define the point in time when EEE becomes WEEE. If the owner decides to sell or give away an EEE, it will still be an EEE and not a WEEE. It is the moment when he or she no longer has a use for the device and decides to throw it away, that an EEE becomes a WEEE. If such a device was to be repaired and used again, it would once more be labelled EEE. If this is not possible or wanted, the device should be disassembled and recyled to regain valuable resources. As little waste as possible should be generated. The process from EEE to WEEE is shown in Fig. 1.

\subsection{Global dimension of electronic devices and WEEE}

Due to the dynamic developments in IT technologies, the electronic market is continuously growing, even during financial crises. A consequence of the steadily increasing number of different available devices is that WEEE is one of the fastest growing waste categories. Because data is not available in all countries, the global extent of e-waste has to be estimated on the basis of production and sales figures. One criterion is the lifetime of an EEE, which however is not a reliable key figure, as many devices, which are no longer in use, are disposed off by the owner instead of being recycled [9].

Currently, exact data concerning the extent of WEEE does not exist. One calculation for 2005 by Robinson [11] regarding the extent of WEEE shows 13.9 million tons minimum, 
Table 1: Categories of EEE and examples [8].

\begin{tabular}{ll}
\hline Categories of EEE & Examples \\
\hline $\begin{array}{l}\text { Large household appliances } \\
\text { Small household appliances }\end{array}$ & $\begin{array}{l}\text { refrigerators, washing machines, microwaves } \\
\text { carpet sweepers, toasters, electric knives } \\
\text { IT and telecommunications equipment }\end{array}$ \\
$\begin{array}{l}\text { Centralised data processing, printer units, } \\
\text { notebook computers }\end{array}$ \\
$\begin{array}{l}\text { Consumer equipment and photovoltaic } \\
\text { panels }\end{array}$ & $\begin{array}{l}\text { Radio sets, video cameras, photovoltaic } \\
\text { panels }\end{array}$ \\
Lighting equipment & $\begin{array}{l}\text { Straight fluorescent lamps, low pressure } \\
\text { sodium lamps }\end{array}$ \\
Electrical and electronic tools (with & $\begin{array}{l}\text { Drills, sewing machines, tool for mowing or } \\
\text { other gardening activities }\end{array}$ \\
the exception of large-scale stationary & Electric trains, video games, coin slot \\
industrial tools) & machines \\
Toys, leisure and sports equipment & $\begin{array}{l}\text { Radiotherapy equipment, nuclear medicine } \\
\text { equipment, analysers, freezers }\end{array}$ \\
Medical devices (with the exception of all & Smoke detector, heating regulators, \\
implanted and infected products) & thermostats \\
Monitoring and control instruments & $\begin{array}{l}\text { Automatic dispensers for hot drinks, for solid } \\
\text { products, for money }\end{array}$ \\
Automatic dispensers &
\end{tabular}

increasing up to 16.8 million tons until 2009. However, this is not the total global extent as countries and regions such as Russia, Canada, Latin America or Africa are not included in the statistics due to a lack of valid data. Robinson estimates the global dimension between 20 and 25 million tons for 2009. The most responsible regions are the European Union, the USA and Australasia. According to the calculations of Schwarzer et al. [12], the extent of WEEE was 20 to 50 million tons worldwide, which means a share of more than $5 \%$ of the total global waste production. The rate of increase is $3-5 \%$ or three times more than in other waste categories. Huisman [10] confirms these numbers, and has calculated an increase of the extent of WEEE since 1990 from 19.5 to 57.4 million tons in 2010. WEEE per capita and year was $0.2 \mathrm{~kg}$ in Kenya (2007), $1.7 \mathrm{~kg}$ in China (2007), $6.7 \mathrm{~kg}$ in Japan (2005) and $15.8 \mathrm{~kg}$ in the United Kingdom (2003) [11]. One reason for the fast growth of WEEE is the significant reduction of the life span of devices during the past decades. For example, the life span of a CPU has been reduced between 1997 and 2005 by two years, from six to four years [13]. Often, we are confronted with planned obsolescence, controlled by the producers who benefit from shorter life spans. On the other hand, under the pressure of competition, the producers have to develop new products and technologies in more and more shortened periods. Consumers change to a new device, although the currently used device, e.g. a TV set, still works. A further factor for reducing the value of a device at an early stage is interoperability, showing the degree of the compatibility of different systems, e.g. common computer-oriented languages or adapters. 


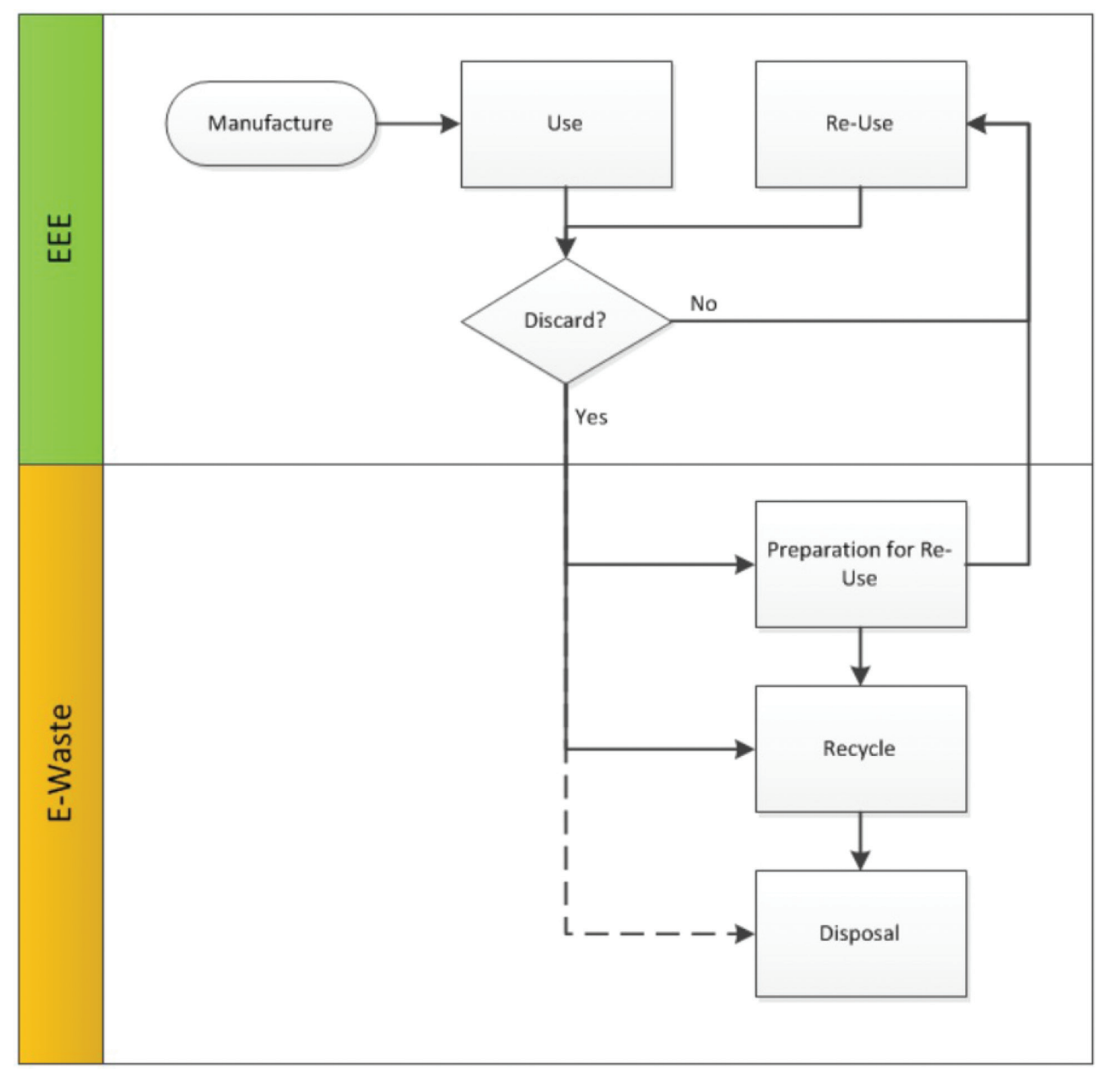

Figure 1: Process of EEE to WEEE [10].

\subsection{Recycling and export}

Complete information about the recycling rate of WEEE doesn't exist. Within the European Union it is for example estimated that around 25\% of the WEEE are professionally recycled. There is no information about the other $75 \%$. This part of WEEE is deposited undocumented, re-used or thrown away with residual waste. The recycling of EEE is rather complex, due to several hundred different materials that comprise an electronic device, the structure of the components and their different combinations. One mobile phone has between 500 and 1000 components, and their separation is complicated and costly. Many producer countries either lack the capacities for professional recycling or the process in these countries means very high costs due to environmental regulations. Another challenge for recycling corporations is the continually changing demand for recycled materials, which means a continual uncertainty regarding their prices. Modern plants have a recycling rate of up to $80 \%$. Further $15 \%$ can be burned in waste incineration plants and 5\% have to be deposited [14].

Parallel to official trade with WEEE, illegal trade exists. Exporters are mostly small companies, which makes the control more difficult. These companies export devices from flea markets, online sales, waste transport corporations, re-use-organisations or from auctions. Low transport costs support the possibility of the economic benefits of e-waste trading. The 
main part of these exports goes to China, India, Ghana or Russia. One reason for their willingness to import used devices is the digital divide, which means the unequal allocation of access to communication technologies [15]. Partly, such devices are exported as development aid. But a high proportion of these devices are inoperable [16]. In these countries a recycling infrastructure as well as corresponding legal rules is generally lacking. Thereby, e-waste is deposited on so-called scrap yards, waste deposits where WEEE is 'recycled' with simple tools by people getting very low wages. This so-called informal recycling ignores peoples' health and the environment [13].

\section{ADVERSE EFFECTS OF INFORMAL RECYCLING - CASE STUDY GHANA}

Ghana is, together with India and China, one of the largest recycling countries. This African country imported 215,000 tons of electronic devices from Europe, the USA and East Asia in 2009. Thereof $30 \%$ were new, and $70 \%$ were used devices. It is estimated that $15 \%$ of the used ones could not be sold anymore because of failures of the hardware or because they were technically outdated. A significant proportion was irreparable and had been disposed off to the scrap yards. The relatively cheap second-hand devices available to people in Ghana provides the possibility of benefitting from the advantages of new technologies. On the other hand, used devices have a shorter life span with the consequence that there is a higher ratio of WEEE to EEE. In 2009, 34\% out of the 280,000 non-functional devices were recycled informally. The remaining devices were either repaired, or disposed of by households. Just around $1 \%$ was handed in at public waste collecting points [17]. The largest informal recycling scrap market in Ghana, with an area of 31.3 hectares, is the Agbogbloshie Scrap Market in Accra, the capital of Ghana. This area is bordered by rivers on two sides. During the rainy season a large part of the scrap market is flooded and as a consequence toxic substances end up in the rivers. In Accra, there are between 4,500 and 6,000 recycling workers. More than $90 \%$ were not born in Accra, but in the poor north of Ghana or in Nigeria or Liberia. They work around 10-12 hours per day for a monthly wage of 70 to 140 Dollars [18]. Another survey shows monthly wages between 380 and 460 Dollars, which would be significantly above the average wage of 93 Dollars per month in Ghana [19-21] and could be an explanation for the high proportion of migrant workers. Besides simple tools, burning is used for isolating different materials or components of the devices. The workers do not use any protective mask or gloves to protect them against the toxic fumes.

The effects of the scrap market on fauna and flora remain unclear. However, with regard to adverse effects on humans several surveys exist. Feldt et al. [22] has compared 2,011 urine samples of Agbogbloshie Scrap Market workers with those of inhabitants of a suburb of Accra, who were not exposed to the emissions of the electronic scrap. The result was a significant higher PAK (polycyclic aromatic hydro carbon) value in the urine of the workers. Additionally, the workers often experienced shortage of breath, cough or dizziness. The survey of Asante et al. [23] also analysed urine samples and showed increased values of iron, antimony and lead. The most hazardous materials in e-waste are lead, antimony, cadmium, mercury and PCBs (polychlorinated biphenyls). Lead is a toxic heavy metal that affects the circulatory and nervous system as well as the kidneys. It can lead to brain displasia in children and to mental disorder [24]. The inhalation of antimony over a longer period has consequences such as irritation of eyes and the lungs, diarrhoea, anacatharsis and stomach ulcer [25]. Cadmium is also an acutely poisonous heavy metal, which in the long run can damage the nervous system and kidneys [26]. Mercury exposure over time affects the kidneys, the lungs and the bones [27]. PCBs affect the human body in several ways. They weaken 
the immune system, have negative effects on mental and physical development as well as disrupt the kidneys and the nervous system, are cancer-causing and lead to infertility of men and women [28].

\section{APPROACHES TO SOLVING THE E-WASTE PROBLEM}

In this section, different approaches for preventing or at least reducing the export of WEEE are highlighted. Currently, various national and international agreements and laws exist for limiting the transport of and trade in e-waste. Here, an overview is given with a focus on the Directives of the European Union and their effects on Austrian legislatives.

\subsection{International agreements}

\subsubsection{Basel convention}

The Basel Convention (Basel Convention on the Control of Transboundary Movements of Hazardous Wastes and their Disposal) [29] has been signed by 170 member states. The goal is the protection of human health and the environment from hazardous waste. It is the first international agreement for a common approach to waste control and management, focusing on the reduction of transboundary waste transport to developing countries.

\subsubsection{OECD decision of the council}

The OECD Decision of the Council concerning the Control of Transboundary Movements of Wastes Destined for Recovery Operations was enacted one month before the Basel Convention. The OECD wanted to establish its own classification system, separating hazardous wastes into two categories. The yellow listed wastes are under strict control while the green listed wastes can be treated like any other good. As a result of this decision, e-waste can be transported within the OECD member states [30].

\subsubsection{EU regulations [31]}

The Directive 2002/96/EG of the European Parliament, and the Council, on waste electrical and electronic equipment (WEEE) aims to prevent, recover and ensure the safe disposal of waste. Additionally, a more effective avoidance of illegal export of waste should be guaranteed. The Directive 2002/95/EC of the European Parliament, and the Council called the RoHS Directive, regulates the restriction on the use of certain hazardous substances in EEE with its objective for an environmentally sound recovery system as well as for the disposal of waste EEE. The WSR Regulation 1013/2006 (Waste Shipment Regulation) integrates the objectives of the Basel Convention and of the OECD Decision of the Council and aims to simplify the controlling process regarding hazardous waste transport, thereby to improve environmental protection.

\subsubsection{Monitoring and prosecution}

Principally, the national authority is responsible for the monitoring of the transport of hazardous wastes and for compliance with regulations, for which they are often unable to cope. Reasons are the challenges in classifying the wastes and regarding identifying the responsible country for the transport or the disposal of the wastes. Furthermore, the different definitions of waste in different countries is a problem [32]. There is a lack of skilled personnel and, therefore, often hazardous waste is not recognized. The international police association INTERPOL supports the national police authorities with training and consulting, as well as by providing a common database and communications platform. 


\subsection{Industry's voluntary initiatives}

For more and more companies it is important to show responsibility toward society by voluntary initiatives regarding hazardous wastes.

\subsubsection{Transparency by certification}

Independent initiatives award labels, showing that a company takes care about the professional handling of electronic devices and e-waste. Some labels consider the whole life cycle and its effects on the environment. In this regard, companies are more and more forced to act as consumers become much more watchful and critical. The US Environmental Protection Agency (EPA) provides two certifications for guaranteeing the professional handling of WEEE. These are the Responsible Recycling Practices (R2) and the e-Stewards standards. Both programmes give recommended courses of action to ensure that a maximum of redundant EEE goes into a formal recycling process and thatcompanies shall optimise their WEEE management in the long run [33]. In 2006, the first global rating system for environmentally friendly IT products was launched, namely, the Electronic Product Environmental Assessment Tool (EPEAT). The independent organisation Green Electronics Council certifies products with a gold, silver or bronze label by evaluating its whole life cycle on the basis of specific criteria. This should also support the strengthening of Green IT [34]. The most recognised label in Europe is the EU Ecolabel, which should guarantee a high quality to the consumer, as well as an environmentally friendly production process. The fitness-for-use principle shall ensure that the product has the same quality as the usual products of the same category [35]. ONCERT is a label in Austria, which is awarded to electronic devices according to criteria like long life cycle and repair friendliness. The label has the categories 'excellent', 'very good', 'good' [36].

\subsubsection{Ecological product design}

For the reduction of hazardous waste, the ecological product design of electronic devices is essential. The most important criteria for sustainable IT products are taking the responsibility for the whole life cycle, an extended product life cycle, the exclusion of toxic substances, transparency, recycling and energy efficiency [37]. One example for ecological product design is phonebloks, an independent initiative, which aims to design a sustainable smartphone. Here, the hardware components are separated, camera, processor, bluetooth etc. are not integrated in a welded case, but are clipped on to a mainboard. Defective parts can be changed easily and at low costs, and an upgrade of the smartphone is feasible [38]. The environmentally friendly laptop D4R (designed for recycling, refurbishment and reuse), sold under the label iameco, has been developed in the framework of the EU project Zerowin. This laptop has a carbon footprint that is $70 \%$ less compared to the average PC. Already the waste in context with the production is reduced, partly by the idea, that waste of the production becomes a resource for another company's production. Additionally, the product design aims to extend the life span of the laptop to a mimimum of 10 years [39].

\subsection{Consumer initiatives}

Several governments, organisations and media provide information about the problem of e-waste, aiming to increase the awareness of consumers for more sustainable products and forcing decision-makers to adhere to environmentally compatible regulations. On the 
basis of such information several consumer initiatives have been launched. In many countries repairing initiatives have been established. Mostly, the repair of a product by professionals is too expensive and does not correlate to the price for a new product. Consumers are, however, reluctant to throw products away after a short using time and therefore launch initiatives, where people repair the products themselves. The internet platform iFixit.com provides repair instructions for several electronic devices to a large online community. The instructions show step-by-step the repair of a mobile phone, a laptop or a toaster, and also the level of difficulty [40]. Furthermore, different initiatives for collecting electronic devices, which are redundant, exist. The aim is, for example, to supply these devices and thereby the resources to the second-hand market or to the recycling process.

\section{CONCLUSION}

Electronic devices are important for our economic and social development, but they are also a huge problem for humans and the environment, too. On the one hand, continuously increasing sales volume needs scarce resources and, on the other hand, the quantity and negative effects of hazardous waste rise critically. Additionally, it is not the countries where these devices are most in use that suffer from the negative effects, but the countries to which used and redundant devices are exported, mostly illegally. Adequate infrastructure and legal regulations for e-waste recycling are absent there. To reduce illegal exports and thereby the problem for humans and the environment, consumers need considerable information about this problem. To a certain degree, consumers can put pressure on producers regarding the avoidance of negative effects on humans and the environment. But it is clear that this can just be a small part of the solution. An essential issue is the harmonisation of the respective legal regulations at the international level. Precondition is a common definition, separating used electronic devices from waste. Detailed information about the quantity and the categories of electronic devices on the market as well as about the e-waste is needed. Additionally, the national authorities have to know the transport routes and the responsible companies or organisations for guaranteeing effective controls and consequent prosecution. Producers and consumers have to be aware, that currently no smartphone or laptop is on the market, which can be recycled $100 \%$. On the other hand, the existing potential for recycling is yet to be reached and has to be optimised significantly. For that, more formal recycling plants are needed at the respective local level in industrial countries as well as in developing countries. However, first of all the avoidance or reduction of e-waste has to be brought into focus. The extension of the life span of electronic devices by repairs and through the availability of spare parts has to be supported. Corresponding incentives for industry in terms of regulations, taxes and subsidies are necessary. A combination of these approaches is needed for solving the ewaste problem in its entirety. Further research should evaluate and compare different measures regarding their potential for solving the e-waste problem.

\section{REFERENCES}

[1] Dowling, S., Apple Press Info, 2014, available at: http://www.apple.com/pr/ library/2014/01/27Apple-Reports-First-Quarter-Results.html.

[2] BMLFUW. Die Bestandsaufnahme der Abfallwirtschaft in Österreich. Statusbericht 2013. Bundesministerium für Land- und Forstwirtschaft, Umwelt und Wasserwirtschaft, 47, 2014. 
[3] Schwarzer, S., De Bono, A., Giuliani, G., Kluser, S. \& Peduzzi, P., E-waste, the hidden side of IT equipment's manufacturing and use. United Nations Environment Programme, 2005.

[4] Yu, L., Understanding information inequality: Making sense of the literature of the information and digital divides. Journal of Librarianship and Information Science, 38(4), pp. 229-252, 2006.

http://dx.doi.org/10.1177/0961000606070600

[5] Brigden, K., Labunska, I., Santillo, D. \& Johnston, P., Chemical contamination at e-waste recycling and disposal sites in Accra and Korforidua, Ghana. Greenpeace International, 2008.

[6] Step Initiative. Solving the E-Waste Problem (Step) White Paper. One Global Definition of E-Waste, Bonn, 2004.

[7] Directive 2012/19/EU of the European Parliament and of the Council of 4 July 2012 on waste electrical and electronic equipment (WEEE).

[8] Directive 2012/19/EU of the European Parliament and of the Council of 4 July 2012 on waste electrical and electronic equipment (WEEE), 16.

[9] Herat, S. \& Agamuthu, P., E-waste: a problem or an opportunity? Review of issues, challenges and solutions in Asian countries. Waste Management \& Research, 30(11), pp. 1113-1129, 2012.

http://dx.doi.org/10.1177/0734242X12453378

[10] Step Initiative. Solving the E-Waste Problem (Step) White Paper. One Global Definition of E-Waste, Bonn, 6, 2014.

[11] Robinson, B.H., E-waste: An assessment of global production and environmental impacts. Science of the Total Environment, 408(2), pp. 183-191, 2009.

http://dx.doi.org/10.1016/j.scitotenv.2009.09.044

[12] Schwarzer, S., De Bono, A., Giuliani, G., Kluser, S. \& Peduzzi, P., E-waste, the hidden side of IT equipment's manufacturing and use. United Nations Environment Programme, 2005.

[13] Huisman, J., Eco-efficiency evaluation of \{WEEE $\}$ take-back systems. In Waste Electrical and Electronic Equipment (WEEE) Handbook, eds V. Goodship \& A. Stevels, Woodhead Publishing Series in Electronic and Optical Materials, Woodhead Publishing, pp. 93-119, 2012.

[14] Ongondo, F., Williams, I. \& Cherrett, T., How are WEEE doing? A global review of the management of electrical and electronic wastes. Waste Management, 31(4), pp. 714-730, 2011. http://dx.doi.org/10.1016/j.wasman.2010.10.023

[15] Babu, B.R., Parande, A.K. \& Basha, C.A., Electrical and electronic waste: A global environmental problem. Waste Management \& Research, 25(4), pp. 307-318, 2007. http://dx.doi.org/10.1177/0734242X07076941

[16] Schwarzer, S., De Bono, A., Giuliani, G., Kluser, S. \& Peduzzi, P., E-waste, the hidden side of IT equipment's manufacturing and use. United Nations Environment Programme, 4, 2005.

[17] Schmidt, C.W., Unfair trade e-waste in Africa. Environmental Health Perspectives, 114(4), p. A232, 2006.

[18] Brigden, K., Labunska, I., Santillo, D. \& Allsopp, M., Recycling of electronic wastes in China and India: workplace and environmental contamination. Greenpeace International, 55, 2005.

[19] Amoyaw-Osei, Y., Agyekum, O., Pwamang, J., Mueller, E., Fasko, R., and Schluep, M., Ghana e-waste country assessment. SBC e-Waste Africa Project, 66:111, 2011. 
[20] Prakash, S., Manhart, A., Amoyaw-Osei, Y. \& Agyekum, O.O., ocio-economic assessment and feasibility study on sustainable e-waste management in Ghana. Öko-Institut e.V. (Freiburg).

[21] Oteng-Ababio, M., When necessity begets ingenuity: e-waste scavenging as a livelihood strategy in Accra, Ghana. African Studies Quarterly, 13(1):1-21, 2012.

[22] Feldt, T., Fobil, J.N., Wittsiepe, J., Wilhelm, M., Till, H., Zoufaly, A., Burchard, G. \& Göen, T., High levels of PAH-metabolites in urine of e-waste recycling workers from Agbogbloshie, Ghana. Science of the Total Environment, 466, pp. 369-376, 2014. http://dx.doi.org/10.1016/j.scitotenv.2013.06.097

[23] Asante, K.A., Agusa, T., Biney, C.A., Agyekum, W.A., Bello, M., Otsuka, M., Itai, T., Takahashi, S. \& Tanabe, S., Multi-trace element levels and arsenic speciation in urine of e-waste recycling workers from Agbogbloshie, Accra in Ghana. Science of the Total Environment, 424, pp. 63-73, 2012.

http://dx.doi.org/10.1016/j.scitotenv.2012.02.072

[24] ATSDR. Toxicological profile for lead. U.S. Department of Health and Human Services, 2007.

[25] ATSDR. Toxicological profile for antimony. Atlanta, GA: U.S.Department of Health and Human Services, Public Health Service, 1992.

[26] ATSDR. Toxicological profile for cadmium. Atlanta, GA: U.S. Department of Health and Human Services, Public Health Service, 2012.

[27] ATSDR (1999). Designing the future The path to greener electronics Mercury. U.S. Department of Health and Human Services, 1999.

[28] ATSDR. Toxicological profile for polychlorinated biphenyls (PCBs). Atlanta, GA: U.S. Department of Health and Human Services, Public Health Service.

[29] UNEP. Basel Convention. On the Control of Transboundary Movements of Hazardous Wastes and their Disposal. UNEP/BRS/2014/3. Geneva, 2014.

[30] Wuttke, J. \& Baehr, T., Praxishandbuch zur grenzüberschreitenden Abfallverbringung. 2. Auflage, 2008.

[31] Höltl, A., Brandtweiner, R. \& Fuhrmann, B., EU legislation advancing ICT to green? In Università Politecnica delle ed. G. Passerini, Marche, Italy; C.A. Brebbia, Wessex Institute of Technology, UK, Environmental Impact II: S, WITPress, Southampton, UK, pp. 479-490, 2014.

[32] Houben, T. \& Ustailieva, E., Waste Shipment Regulation: Ultimum Remedium For Preventing Illegal Waste Shipments?

[33] EPA, OSWER, and Office of Resource Conservation and Recovery, Certification Programs for Electronics Recyclers, 2014, available at: https://www.epa.gov/lawsregulations

[34] Green Electronics Council, Environmental Benefits of 2011 EPEAT Purchasing Continued Global Uptake and Positive Environmental Impact. EPEAT Environmental Benefits Reports, 2011.

[35] European Union. Regulation (EC) No 1013/2006 of the European Parliament and of the Council of 14 June 2006 über on shipments of waste, 2006.

[36] ON. ONR 192102 Gütezeichen für langlebige, reparaturfreundlich konstruierte elektrische und elektronische Geräte. Austrian Standards Institute, 21, 2014.

[37] Cobbing, M. \& Dowdall, T., Green Gadgets: Designing the future, 2014.

[38] Hakkens, D., About Phonebloks, 2015, available at: https://phonebloks.com/en/. 
[39] Hickey, S., Fitzpatrick, C., Maher, P., Ospina, J., Schischke, K., Beigl, P., Vidorreta, I., Yang, M., Williams, I.D. \& den Boer, E. (2014). A case study of the D4R laptop, volume 167, chapter Waste and Resource Management, Proceedings of the Institution of Civil Engineers, wr3 edition, pp. 101-108.

[40] Wiens, K. \& Soules, L., Where we are coming from - iFixit, 2015, available at: https:// www.ifixit.com/Info/background abgerufen am. 